\title{
ТАМАШ КРАУС
}

\section{ОТНОШЕНИЯ МЕЖДУ ИСТОРИОГРАФИЕЙ И ПОЛИТИКОЙ ПАМЯТИ}

\section{Тезисы в зеркале споров об оценке советско-германского}

пакта о ненападении ${ }^{1}$

Кто несет ответственность за войну?

\section{THE CONNECTIONS BETWEEN HISTORIOGRAPHY AND MEMORY POLITICS}

\author{
Debate about the Interpretations of the Soviet-German \\ Non-Aggression Pact \\ Who was responsible for the war?
}

This essay discusses the historiography and some aspects of memory politics (Erinnerungskultur) concerning the outbreak of World War II. In the European Union and the United States the dominant interpretation of history is that the outbreak of World War II was the consequence of the Soviet-German Treaty of Non-Aggression (Molotov-Ribbentrop Pact) concluded on 23 August 1939, by the leading circles of the two 'totalitarian dictatorships'. Today in Eastern Europe some politicians and historians go even further and transfer major responsibility for the outbreak of the war to Stalin. The most important historiographical trend, however, also focuses on the antecedents of the Soviet-German Treaty of Non-Aggression. The followers of this approach simultaneously stress the responsibility of the other great powers whose leaders concluded a treaty with Hitler in September 1938 (the Munich Pact, which was the consequence of the policy of appeasement) and also leaders of certain small states, who made separate 'deals' and agreements with Hitler. For example, even prior to the outbreak of the war, the Polish establishment perceived the Soviet Union and not Germany as Poland's major enemy. Unfortunately, there are always historians, who cannot resist the pressure of power elites, who - with ever increasing apparatuses and capital - appropriate and falsify history for the sake of (geo)political interests. The author of this article argues that the Soviet-German Treaty of Non-Aggression was signed by the Soviet Union as it did not want to bear alone all the burdens of a war with Nazi Germany.

Keywords: Russian historiography, memory politics, Second World War (WWII), Munich Treaty, Molotov-Ribbentrop Pact, 1939, Soviet Union, Nazi Germany

1 Конференция Института всеобщей истории Российской академии наук по случаю 80-й годовщины начала Второй мировой войны. (2-3 октября 2019 г.) Отредактированная версия лекции

DOI: 10.38210/RUSTUDH.2019.1.2 


\section{І. ПОЛИТИКА И ИСТОРИЯ}

Уже 30 лет тому назад по существу все было ясно. В процессе т.н. смены режима, в переходе ко второму изданию капитализма, либералы и националисты-консерваторы сдают старый исторический нарратив, в том числе нарратив, интерпретацию, восприятие 2-й мировой войны. Многие не хотели понять, что этот глобальный политический переворот ведет к гегемонии старой консервативной американской интерпретации холодной войны. Либералы в духе консерватизма предали старый антифашистский, антинацистский неподписанный, но много раз декларированный союз, который господствовал до конца 80-х годов. А вот идеологические рамки переворота: отождествление СССР с нацистской Германией, преувеличениедостоинствзападныхсоюзников, недооценка советских военных усилий, прямая фальсификация начала Второй мировой войны. Эти тезисы сегодня являются общей точкой правительственной политики памяти восточно-европейских стран. Большинство историков поддерживало эту тенденцию мышления и действия. Все оттенки „старого”, традиционного подхода попали под термин сталинизма. В последнее десятилетие ничего существенного не появилось, только русофобия укрепилась в пропагандистских аппаратах режимов. В этих странах политика памяти контролируется сетью музеев памяти, государственными комитетами по истории и.т.д. От Львова до Будапешта, от Вильнюса до Варшавы эти институты сохраняют политические и моральные позиции властвующих элит. Новые авторитарные режимы этих стран сотворили специальный образ и особый взгляд на историю. Этот взгляд исходит везде из исключительно популистско-националистических соображений. Более того эти режимы и их основные политические позиции поддерживаются в Евросоюзе сверху. Например, несколько дней назад консервативнолиберальное большинство Европарламента приняло резолюцию о Второй мировой войне, в которой на русофобской, антилевой и антикоммунистической основе почти отождествляется - в отношении начала второй мировой войны - роль СССР с ролью германофашистской империи. Резолюция даже не упомянула положительную роль антифашистского сопротивления. ${ }^{2}$

2 Ссылка:https://www.europarl.europa.eu/news/en/press-room/20190917IPR61204/europe -must-remember-its-past-to-build-its-futurecm Левый протест против резолюции см.: (https://www.europarl.europa.eu/news/en/press-room/20190917IPR61204/europe-mustremember-its-past-to-build-its-future) (дата обращения: 31 октября 2019.) 
Впрочем у нас в 80-е годы ЦК ВСРП уже ни разу не принимал резолюцию по вопросам истории.

\section{II. ЦЕЛЬ И ФУНКЦИЯ ИСКАЖЕНИЙ}

Лет 10 назад в связи с 70-летней годовщиной заключения советскогерманского договора о ненападении полмира спорило о возможностях новой интерпретации этого соглашения. Эта полемика «просочилась» и в Венгрию. Ставка и цель серии дискуссий, начавшейся одновременно во многих странах, состояли в том, чтобы представить советско-германский договор о ненападении важнейшим документом, приведшим к началу второй мировой войны и свидетельствующим об «общей ответственности тоталитарных диктатур». ${ }^{3}$

Сегодня ситуация не лучше. ВПраге, например, сняли статую маршала Конева, в Украине после пронацистской, ужасно-авантюристской политики памяти Порошенко-Вятровича, новый президент, юморист Зеленский, в роле историка просто заявил как истину сразу после выборов, что антисемиты-убийцы, Бандера и Шухевич, защищали Украину в войне и останутся национальными героями. В Будапеште первый союзник Гитлера, Хорти, получил бюст на площади Свободы. В России некоторые историки и политики даже популяризируют Власова и власовцев. Не удивительно, если чешские „власовцы” адекватно восприняли это завещание.

Хотя всё больше и больше появляется свободно исследуемого архивного материала, число фальсификаций, искажений также национализма, в историографии. История сама стала игрушкой геополитических столкновений не без непосредственного участия историков.

Кажется все с ума сошли в нашем регионе. Но нет, есть причина оглупления. В Восточной Европе идеологически оправдать новое здание олигархической системы, второго издания капитализма без традиционного национализма невозможно, потому что этот тип национализма авторитарный, ультраконсервативный, антинаучный, агрессивный, содержит в себе наследие режимов периода между мировыми войнами и времени второй мировой войны.

3 В разоблачении и опровержении этого, помимо публикации российских архивных источников, большую роль сыграл фонд «Историческая память» и его директор А.П. Дюков. См.: А.П. Дюков: «Пакт Молотова-Риббентропа» в вопросах и ответах. Фонд «Историческая память». (М., 2009) 
Итак. Эти дискуссии однозначно показали основное противоречие: в то время как, с одной стороны, российские архивы открыли доступ и опубликовали огромное количество архивных материалов, с другой стороны, в спорах, проходивших повсеместно от Америки до Европы, именно архивные источники играли наименьшую роль. Еще более странно, что чем дальше мы двигаемся в Европе на восток, тем меньшее значение придается архивным источникам. На востоке Европы политическая и легитимационная цель, быть может, еще более очевидна, чем на западе: снять с Гитлера и его союзников часть ответственности за мировую войну и нападение на СССР и переложить её на Сталина для того, чтобы замолчать историческую ответственность «политики умиротворения» западных держав (1934-1939) и дипломатии малых восточноевропейских государств в усилении нацистской Германии, расширении её экспансии и развязывании мировой войны.

Ясно, что осуществляется ревизия вопроса об ответственности. Насколько мне известно, за последние 30 лет не обнаружено ни одной группы источников, которая доказывала бы, что отношения между СССР и нацистской Германией, несмотря на различные случаи «тактического сотрудничества», в основном и по существу определялись бы не взаимной враждебностью. Казалось бы, само собой разумеется, что с момента своего возникновения гитлеризм считал своим главным врагом «иудео-большевистский» СССР и марксизм, ведь нацисты провозглашали это везде от «Mein Kampf»-адо ихнаиболее популярного пропагандистского издания 1937 г., «Der Ewige Jude», и подобные, а также всегда и последовательно декларировали это на своих массовых собраниях и мероприятиях, а 22 июня 1941 г. однозначно доказали и на практике. Так зачем же исторической науке пересматривать столь очевидные вещи? До смены режима практически никому, тем более серьезным историкам, не приходило в голову утверждать, что заключение пакта было с советской стороны результатом некоего заранее определенного плана. Не было и нет подтверждающих это достоверных источников, документов, хотя, как я отмечу ниже, за последние 20 лет неоднократно совершались попытки фабрикации фальшивых документов, манипулятивный характер которых вскоре обнаруживался с полной ясностью.

В Венгрии эта дискуссия прошла в политических газетах и журналах, а также на радио и телевидении на таком жалком уровне, что приходится задуматься над резким падением качества 
«мейнстрима» отечественной исторической публицистики по этой тематике. 20-30 лет назад нельзя было представить, что представители венгерской исторической науки, включившиеся в крупную международную дискуссию, могут позволить себе пренебречь массой свежеопубликованных источников ради одного-двух сфабрикованных документов и упорно повторять свои идеологические фантасмагории. В настоящее время это стало возможным. ${ }^{4}$ Провозглашение абсурдных концепций, прежде всего идеи о том, что вторая мировая война вспыхнула в результате пакта, и ответственность за это лежит главным образом на Сталине, служит стиранию грани между палачом, нацистской Германией, и жертвой, СССР. Не случайно, что принятые в науке исследования и аргументация теряют при этом всякое значение. Вместо этого просто объявляется новый «результат». Конечно, в связи с похожей темой и теми же авторами уже и ранее говорилось о большом вреде, наносимом указанным методом «переписывания истории», который под флагом научного подхода проник в СМИ и господствует в них, практически не встречая никакого сопротивления. ${ }^{5}$ Открытое и циничное пренебрежение документами и архивными источниками, безграничное распространение теоретической неподготовленности и неосведомленности, надменный отказ от всяких научных соображений при обращении к широкой публике, - все это не только подрывает доверие к упомянутым историкам, но, к сожалению, наносит вред и исторической науке в целом. ${ }^{6}$

4 Журнал Eszmélet (Эсмелет) часто публикует критику таких фальсификационных материалов. Последним скандалом был фальсификация (Андреей Пето) интерпретации фото советского военного фотографа, Эв. Халдера. Об этом см. анализ Петера Пастора: PÁszTor PÉTER: Eszmélet, № 121.

5 Об этом см. объективную полемическую статью, написанную несколько лет назад: SIPOS PÉTER, „Hozzászólás egy sajátos recenzióhoz” (По поводу одной своеобразной рецензии), Élet és Irodalom, 2005. március 11.

6 Тот же самый историк, который уже много лет решительно высказывает свое мнение по всем вопросам российско-советской тематики, хотя ни разу не видел ни одного источника на русском языке. О разоблачении такого подхода см.: WERTH MÁRK, „AZ Ungváry jelenség" (Феномен Унгвари), Eszmélet (осень 2002), № 55; об обсуждении этой проблематики см.: Konok PÉTER, KRAUSZ TAMÁs, SIPOS PÉTER, UngVÁRY KRISZTIÁN, VARgyAI GYULA, ZEIDLER MIKLós, „Magyarország és a II. világháború” (Венгрия и вторая мировая война), Eszmélet (весна 2003), № 61. 


\section{III. ОБ ИСТОРИЧЕСКИХ ПРЕДПОСЫЛКАХ ПАКТА}

Историки убедительно показали, что заключение советско-германского договора о ненападении объясняется тремя основными причинами, которые обязательно должны учитываться при оценке исторического значения, «ценности» пакта.' Намерения Германии были очевидны: немцы не хотели войны на два фронта. В своем известном и пространном труде об истории второй мировой войны Дёрдь Ранки уже в начале 1970-х гг. сформулировал тот научный консенсус, о ревизии которого в наши дни я говорил выше. Имеет смысл остановиться на мнении Ранки подробнее, поскольку позже оно укоренилось в венгерской исторической науке, хотя в наши дни на повестке дня оказалось как раз выкорчевывание этих корней. «После Мюнхенского соглашения, - писал Ранки - заключением которого правительства Англии и Франции, ссылаясь на сохранение мира, пожертвовали своими чехословацкими союзниками и молчаливо признали немецкую гегемонию в Юго-Восточной Европе, направляя экспансионистские устремления Германии на Восток, советское правительство было вынуждено пересмотреть свою прежнюю политику. Если ранее, руководствуясь идеей антифашистской борьбы, оно стремилось к заключению союза исключительно с западными державами, то с весны 1939 г. его политика стала более осторожной из-за опасения, что западные державы могут вынудить СССР воевать с Германией в одиночку. Поскольку западные державы даже на переговорах летом 1939 г. не выказывали готовности к заключению серьезного военного договора, советское правительство приняло предложение германии о заключении договора о ненападении». ${ }^{8}$

Обобщая: 1. Основной причиной подписания пакта (и секретного протокола9) советской стороной была т. н. политика умиротворения,

7 Об этом см., например: Geoffrey Roberts, Stalin's Wars. From World War to Cold War, 1939-1953 (New Haven and London: Yale University Press, 2006)

8 RÁNKI GYÖRGY, A második világháború története (История второй мировой войны) (Budapest: Gondolat, 1973), 7.

9 О том, насколько секретным был этот протокол для Англии и США, хорошо свидетельствует заявление, которое было сделано на московской конференции историков, организованной по случаю 70-летней годовщины заключения пакта. На конференции говорилось о том, что уже в день подписания пакта американцы узнали о секретном протоколе из донесения американского разведчика, работавшего в германском посольстве. Не случайно, что через несколько недель после заключения договора о нападения даже и Черчилль, выступая в Палате общин, по существу взял 
которая проводилась западноевропейскими великими державами после прихода Гитлера к власти и достигла своей высшей точки в заключении Мюнхенского соглашения. Эта политика западных стран продолжалась до самого начала войны (попытка добиться «второго Мюнхена»), причем даже несмотря на беспримерную агрессивную экспансию нацистской империи, несмотря на Аншлюс, раздел Чехословакии, первый и второй Венский арбитраж и Данциг. Вопреки всем международным договорам и соглашениям, Англия и Франция проглотили почти все, что предложил им Гитлер.

2. Все попытки советского руководства заключить какой-либо союз с Польшей и остальными восточноевропейскими странами были неудачны. Министр иностранных дел Польши Бек, несмотря на сильное давление со стороны Франции, не обратился к правительству СССР в интересах заключения договора о взаимной помощи даже тогда, когда 23 августа 1939 г. Риббентроп прилетел в Москву: «Он по-прежнему был твердо убежден в том, что независимая Польша имеет больше шансов достичь соглашения с Гитлером. Он считал, что Советская Россия начинает отворачиваться от Европы, и это было для него хорошей новостью». ${ }^{10}$

3. Видя всеобщее противодействие своей политике «коллективной безопасности», Сталин вместе с тем чувствовал растущую угрозу, вытекающую из полной изоляции СССР на международной арене. Ктому же Сталин знал (ведь именно тогда он совершил «непростительную ошибку»: обезглавил Красную армию), что СССР не подготовлен к войне. В 1939 г. отсрочка начала войны представлялась ему вопросом жизни и смерти, ведь после Мюнхена стало очевидным, Гитлер обратится на Восток. Даже и критически настроенные историки не подвергают сомнению неизбежность заключения договора о ненападении, признавая, что советское правительство в конечном итоге могло выбирать лишь между заключением договора и войной. В зависимости от исторического подхода и исследовательской позиции пакт может считаться продуктом «мудрости» и предусмотрительности (как это обычно наблюдалось в советской исторической науке) или

его под защиту, высказав мнение, что появление Красной армии на спорных границах все же лучше, чем приближение Вермахта к советским территориям.

10 A. J. P. TAYLOR, A második világháború okai (Причины второй мировой войны) (Budapest: Scolar Kiadó, 1998), 311. 
вынужденным шагом и результатом допущенных ранее ошибок.1 Однако эти группы причин включают в себя такую цепь причин и следствий, которая не может быть произвольно разорвана.

\section{IV. ПОЛЬША И ПРИБАЛТИКА: РЕВИЗИЯ ПОЛИТИКИ ПАМЯТИ}

Архивные источники, опубликованные ныне в России, однозначно подтверждают тот «издавна» очевидный факт (если в наши дни еще существуют очевидные факты), что определяющие группировки властной элиты Польши и балтийских государств уже в 1939 г. считали своим главным врагом СССР, а не нацистскую Германию. А для СССР балтийские государства, первоначально созданные Антантой, являлись важным военно-стратегическим регионом на случай войны: находясь под немецким влиянием, они могли блокировать Балтийский флот, а Вермахт получил бы благоприятную позицию для наступления на Ленинград. По этим причинам советское руководство настойчиво добивалось нейтралитета соседних балтийских государств. Стремясь укрепить его, оно весной 1939 г. сделало попытку дать совместно с западными державами гарантии балтийским государствам, однако эта попытка оказалась безуспешной. Еще шли переговоры с Англией и Францией, когда 7 июня Литва и Эстония заключили с нацистской Германией договоры о ненападении (таким образом, первый «договор о ненападении» с Германией заключил отнюдь не СССР!). После этого этот регион посетили руководитель Абвера адмирал Канарис и начальник Генштаба сухопутных сил Вермахта генерал Франц Гальдер. В то время как позиции Германии в балтийских государствах заметно укрепились, советские руководители чувствовали, что оправдываются их «давние» опасения: Прибалтика становится плацдармом для нападения на СССР. В этой ситуации снова возникла мысль о том, что СССР либо должен практически в одиночку вступить в войну с Германией, либо заключит с ней соглашение. ${ }^{2}$ Как советские руководители, так

11 DIószegI ISTVÁN, A hatalmi politika másfél évszázada (Полтора столетия властной политики) (Budapest: História Könyvtár, MTA TTI, 1997), 430.; SIPOS PÉTER, A II. világháború és az azt követő békék (Вторая мировая война и последовавшие за ней мирные договоры) (Budapest: IKVA, 1991), 25-35.

12 А.П. Дюков «Пакт Молотова-Риббентропа»...; О.Н. КЕН, А.И. РУПАСов, Москва и страны Балтии: опыт взаимоотношений, 1917-1939 г2. - Страны Балтии и Россия: общества и государства (М., 2002) 
и западные политики с самого начала истолковывали пакт именно в этом смысле: в своем конфиденциальном сообщении от 27 сентября 1941 г. (которое было передано Сталину, Молотову, Берии и Меркулову в ноябре того же года) английский посол в СССР сэр Стенфорд Криппс так информировал свое начальство: «Нет никакого сомнения, что непосредственной причиной подписания этого пакта являлось, как это неоднократно заявляли советские лидеры, их желание остаться вне войны. Они считали возможным осуществить это, хотя бы на время, путем заключения соглашения с Германией». ${ }^{13}$

1 августа 1939 г. советский агент, работавший в эстонском представительстве в Англии, доносил в соответствующую инстанцию советской разведки о том, что в Англии «особенно часто передает сообщения о германском влиянии в Эстонии и Латвии Mediterranean Press Agency, которое получает информацию из Парижа, и связано также с советами».14 Документы разведки, содержащие сведения о германском «контроле» над балтийскими государствами, особенно важны потому, что они показывают, что мог в действительности знать Сталин о фактах «окружения» СССР.

Конечно, в данном случае речь идет о длительном процессе, Сталин и его коллеги разобрались в указанном выше аттитюде малых восточноевропейских государств и Польши не внезапно и не в 1939 г. Позиция Польши состояла в том, что с удивительной и неизменной слепотой связывала свои интересы с нацистской Германией в противовес СССР и Литве. Необходимо принять во внимание, что польская властная элита даже в августе 1939 г. противилась заключению такого англо-франко-советского военного соглашения, которое предусматривало бы вооруженную защиту Польши, что в некоторой степени объясняет вялое ведение французами и англичанами московских переговоров в августе 1939 г. Если посмотреть источники, то выясняется, что это антисоветское мышление и соответствующая политическая практика имели глубокие корни. Уже в 1933 г., когда Лига Наций готовилась ввести санкции против гитлеровской Германии, отозвавшей своих представителей с конференции по разоружению, Польша заверила руководство нацистской империи о несогласии с введением санкций и сделала предложение о заключении союза

13 Прибалтика и геополитика. 1935-1945. Рассекреченные документы Службы внешней разведки Российской Федерации. (Составитель: Л. Ф. Соцков). Служба внешней разведки Российской Федерации. Архив СВР России. (М., 2009), 142.

14 Прибалтика и геополитика. Док. № 23-27. 
против СССР, что показалось слишком радикальным даже нацистским руководителям. Все же в конце концов в январе 1934 г. была подписана совместная германо-польская декларация о мирном урегулировании спорных вопросов. Когда же в сентябре 1934 г. СССР предложил Польше подписать совместную декларацию о неприкосновенности балтийских государств, Польша отклонила это предложение под давлением немцев и из-за территориальных претензий Варшавы к Литве. Польские руководители сообщили о своей готовности связать судьбу Польши с Германией и Парижу. Польша следовала за нацистской Германией и тогда, когда начался конкретный «пересмотр» европейских границ. В марте 1938 г. в рамках провокации, организованной на польсколитовской демаркационной линии, Польша предъявила Литве ультиматум, в котором под угрозой применения силы потребовала официального признания перехода к Польше территорий, занятых польской армией в 1920 г. и аннексированных в 1922 г. Эта бесславная историческая роль Польши была увенчана польской властной элитой участием в агрессии нацистской Германии, закончившейся разделом Чехословакии, когда Польша получила Тешин. ${ }^{15}$ «Мудрость» польской властной элиты сравнима лишь с «мудростью» элиты венгерской.

Польша считала определяющими свои отношения с немцами и в связи с другими восточноевропейскими странами. В апреле 1935 г. на основании секретного телеграфного сообщения из Румынии (на документе не обозначена точная дата, однако речь идет о том периоде времени, когда Геринг посетил Варшаву) Сталина информировали о том, что Польша и Германия принимают все меры к срыву переговоров между СССР и Румынией о взаимной поддержке. «20 апреля поляки под угрозой разрыва польско-румынского союза предложили Румынии ... взять курс на сближение с Германией. Румынский король заявил полякам, что пакта с СССР он без Германии и Польши не заключит... Король намерен проводить политику активного сближения с Германией...». Далее подписавший документ заместитель начальника ИНО ГУГБ НКВД Слуцкий обратил внимание советского руководителя и на то, что « между польским и германским генеральными штабами заключена конвенция, направленная против СССР». ${ }^{16}$

15 М.И. МЕльтюхов, 17 сентября 1939: советско-польские конфликты, 1918-1939 (М., 2009), 168-82.

16 Секреты польской политики. Сборник документов (1935-1945). Составитель: Л. Ф. Соцков. (М., 2009), 21. 
Позже Сталин получил немало других документов, отражавших антисоветскую политическую стратегию польского правительства и балтийских государств и свидетельствовавших о том, что в интересах сохранения хороших отношений с нацистской Германией поляки и руководители балтийских государств отвергали заключение «двусторонних пактов» с СССР. Например, в сентябре 1937 г. тот же Слуцкий направил Сталину, Молотову и Ворошилову копию секретного сообщения, посланного послом Польши в Эстонии министру иностранных дел Польши. Этот документ информировал министра о том, что, по сведениям эстонских военных источников, эстонская позиция в связи со слухами о советских предложениях, сделанных Латвии и Литве с целью улучшения отношений, однозначна. Конкретно это означало, что по вопросу «об установлении более тесной связи с Москвой в форме двусторонних пактов» «Эстония ни на какие комбинации не согласится». ${ }^{17}$ Составитель другого секретного документа, директивы № 2304/2/37 польского Генштаба от 31 августа 1937 г., 18 уже фантазировал «об уничтожении всякой России». Что же касается практических целей, то польская военная разведка намеревалась создать из эмигрантских элементов сепаратистские движения, которые способствовали бы отторжению от СССР Кавказа, Украины и Средней Азии. ${ }^{19}$ В этой организационной работе, центром которой был Париж, акцент откровенно, без сомнения ставился на эмигрантском «националистическом радикализме», как говорится в секретном документе, «в стиле Пилсудского». ${ }^{20}$ Все это заставило Сталина и других советских руководителей глубоко задуматься о действительных намерениях польских политиков, вероятно, вспомнив при этом и о «разочарованиях» 1920 г.

Руководители балтийскихстран, каки польские политики, находились в плену иллюзорной надежды на возможность балансировать между нацистской Германией и СССР, избегая при этом поглощения их стран великими державами. Однако секретный протокол к пакту МолотоваРиббентропа показал, что во время войны военно-стратегические

\footnotetext{
17 Там же. 218.

18 Там же. 201. и далее.

19 Там же. 204-05.

20 Там же. 208., 213., 215.
} 
интересы «пересилят» все остальные соображения. ${ }^{21}$ Пакт, содержавший в себе перспективу аннексии Прибалтики, стал актуальным поздней весной 1940 г. потому, что радикально изменилось военное положение. После Норвегии и Дании нацистская Германия готовилась расправиться с Францией. В изменившихся стратегических условиях СССР продвинул свои границы практически до Германии. В русле этих соображений в июне 1941 г. в соответствии с постановлением ЦК ВКП(б) И Совета Народных Комиссаров («О мерах по очистке Литовской, Латвийской и Эстонской ССР от антисоветских и социально-опасных элементов») началась депортация тех групп населения, которые потенциально могли усилить лагерь антисоветских сил или возглавить его. Постановление, выработанное в спешке в НКВД, первоначально относилось лишь к Литве, а позже, в последний момент, в него от руки вписали Эстонию и Латвию. Нужно отметить, что в Прибалтике социальные группы частных собственников, связанные с капиталистическим строем, не просто служили базой своих правительств, но видели в нацистской Германии союзника, который мог гарантировать сохранение капитализма в противовес советской системе государственного социализма. ${ }^{22}$ (Другой вопрос, что быстрая «советизация» Прибалтики и связанные с ней депортации поставили на сторону немцев и такие группы общества, которые в другом случае, вероятно, могли бы остаться нейтральными). Почти одновременно с нападением нацистов на СССР в крупных городах Литвы, а затем и в Латвии и Эстонии начались совершавшиеся местными «активными национальными силами» кровавые антикоммунистические и антисемитские расправы, которые влились в организованный немцами процесс Холокоста и о которых позже, уже «видя достигнутые результаты», с большим признанием доносил в Берлин даже командир айнзатцгруппы «А». ${ }^{23}$

21 В советские времена секретный протокол никогда не упоминался, отрицалось даже само его существование. В конце 80-х гг. будущий известный «разоблачитель» Д. Волкогонов (начальник Главного политического управления СА и ВМФ) во время своего пребывания в Будапеште в присутствии автора этих строк опровергал существование тайного протокола, хотя к тому времени мы уже цитировали его в нашей биографии Сталина, ведь текст протокола давно циркулировал в различных западных изданиях. Академик Ранки рассказывал, что подпись Молотова на копии пакта, хранившейся в Германии, была подлинной, аутентичной.

22 А.П. Дюков «Пакт Молотова-Риббентропа», 29-31, 47-52. ильмЯРВ М. Балтийские страны в 1939-1940 гг.: замыслы и возможности. - Международный кризис 1939-1941 гг.: От советско-германских договоров 1939 года до нападения Германии на СССР. (М., 2006), 276.

23 См.: Донесение командира айнзатцгруппы «А» бригаденфюрера СС Ф. Шталеккера о деятельности группы в оккупированных областях Прибалтики и Белоруссии (Не 


\section{V. О КРИТЕРИИ ОЦЕНКИ}

Проблему оценки пакта и секретного протокола необходимо отделить от оценки германо-советского договора о дружбе 28 сентября 1939 г. При оценке пакта мы не последовали старой идеологической привычке к «морализированию» и искали и приводили рациональноисторические соображения, в то же время договор о «дружбе» во время войны запятнал грязью поведение советского руководства. Конечно, упоминания о «дружбе» в сталинской дипломатии служили ничему иному, как желанию успокоить немцев относительно того, что СССР будет соблюдать предписания договора о ненападении. И все же, несмотря на это, договор о «дружбе», приведя к прекращению антифашистской пропаганды, оказал катастрофическое влияние на обороноспособность СССР, на все международное рабочее движение и антифашистское общественное мнение. Этот договор до сих пор служит идеологическим средством для тех, кто пытается вывести проблематику советско-германского сотрудничества далеко за первоначальные рамки, преследую цель, о которой упоминалось выше. Консенсусным мерилом оценки германо-советского договора о ненападении может служить уже упомянутое выступление Черчилля по радио, в котором он охарактеризовал пакт и его последствия следующим образом: «Россия проводитхолодную политику собственныхинтересов. Мыбы предпочли, чтобы русские армии стояли на своих нынешних позициях как друзья и союзники Польши, а не как захватчики. Но для защиты России от нацистской угрозы явно необходимо было, чтобы русские армии стояли на этой линии. Во всяком случае, эта линия существует и, следовательно, создан Восточный фронт, на который нацистская Германия не посмеет напасть». 24 Да, 30-е годы были временем, когда реальные или мнимые интересы столкнувшихся друг с другом националистических государств, как мы видели это на примере Польши, балтийских стран или мюнхенской политики, оказались сильнее всех разумных расчетов и иных соображений, негативно отразившись в итоге на судьбе самих этих государств. На самом деле в 1939 г. «холодная политика собственных интересов» уже не могла никого удивить. В Европе к тому времени не было ни одного государства, готового к самоограничению. Напав

ранее 31 октября 1941 г.). - Прибалтика. Под знаком свастики (1941-1945). Сборник документов. Объединенная редакция МВД России. Ассоциация «Военная книга» (М., 2009). Положению в Литве и Латвии Шталеккер противопоставил ситуацию в Белоруссии, где «население не готово ни к каким погромам»., 160-63.

24 Winston ChURChILL, The Second World War, Vol. II. (London: Paperback, 1948), 42. 
22 июня 1941 г. на СССР, нацистская Германия сама разорвала пакт о ненападении. Таким образом, стремление задним числом представить пакт в качестве документа какого-то стратегического союза, «логично» следующего из природы «тоталитарных диктатур», является не более, чем простой фальсификацией истории, деградацией исторической науки до уровня «памфлетописания», превращением исторической науки в игрушку современной политики. Служение политике памяти со стороны историков огромная ответственность, поэтому лучше служить исканию истины и собственной совести.

Tamás Krausz - D.Sc. in History, Professor Emeritus, Russian Studies Centre, Department of Eastern and Central European History and Historical Russistics, Faculty of Humanities, Eötvös Loránd University (Hungary, Budapest, 1088 Múzeum krt. 6-8.).

E-mail: centre@russianstudies.hu

ORCID: https://orcid.org/0000-0003-3717-9887 